\title{
Flax (Linum usitatissimum L.): A Potential Candidate for Phytoremediation? Biological and Economical Points of View
}

\author{
Muhammad Hamzah Saleem ${ }^{1}$, Shafaqat Ali ${ }^{2,3, *}{ }^{\circ}$, Saddam Hussain ${ }^{4}(\mathbb{D}$, \\ Muhammad Kamran ${ }^{5}{ }^{(0}$, Muhammad Sohaib Chattha ${ }^{1}$, Shoaib Ahmad ${ }^{1}$, Muhammad Aqeel ${ }^{6}(\mathbb{0}$, \\ Muhammad Rizwan ${ }^{2}\left(\mathbb{D}\right.$, Nada H. Aljarba ${ }^{7}$, Saad Alkahtani ${ }^{8}$ and Mohamed M. Abdel-Daim ${ }^{8,9}$ \\ 1 MOA Key Laboratory of Crop Ecophysiology and Farming System in the Middle Reaches of the Yangtze \\ River, College of Plant Science and Technology, Huazhong Agricultural University, Wuhan 430070, China; \\ saleemhamza312@webmail.hzau.edu.cn (M.H.S.); sohaib.psp@webmail.hzau.edu.cn (M.S.C.); \\ shoaib17@webmail.hzau.edu.cn (S.A.) \\ 2 Department of Environmental Sciences and Engineering, Government College University Allama Iqbal \\ Road, Faisalabad 38000, Pakistan; mrazi1532@yahoo.com \\ 3 Department of Biological Sciences and Technology, China Medical University, Taichung 40402, Taiwan \\ 4 Department of agronomy, University of Agriculture, Faisalabad 38040, Punjab, Pakistan; \\ shussain@uaf.edu.pk \\ 5 Key Laboratory of Arable Land Conservation (Middle and Lower Reaches of Yangtze River), Ministry of \\ Agriculture, Huazhong Agricultural University, Wuhan 430070, China; kamiagrarian763@gmail.com \\ 6 State Key laboratory of Grassland Agro-Ecosystems, School of Life Science, Lanzhou University, \\ Lanzhou 73000, China; aqeelbutt99@gmail.com \\ 7 Department of Biology, College of Science, Princess Nourah bint Abdulrahman University, Riyadh 11474, \\ Saudi Arabia; Nhaljarba@pnu.edu.sa \\ 8 Department of Zoology, College of Science, King Saud University, Riyadh 11451, Saudi Arabia; \\ salkahtani@ksu.edu.sa (S.A.); abdeldaim.m@vet.suez.edu.eg (M.M.A.-D.) \\ 9 Pharmacology Department, Faculty of Veterinary Medicine, Suez Canal University, Ismailia 41522, Egypt \\ * Correspondence: shafaqataligill@gcuf.edu.pk; Tel.: +92-419-201-566
}

Received: 6 March 2020; Accepted: 8 April 2020; Published: 13 April 2020

check for updates

\begin{abstract}
Flax (Linum usitatissimum L.) is an important oil seed crop that is mostly cultivated in temperate climates. In addition to many commercial applications, flax is also used as a fibrous species or for livestock feed (animal fodder). For the last 40 years, flax has been used as a phytoremediation tool for the remediation of different heavy metals, particularly for phytoextraction when cultivated on metal contaminated soils. Among different fibrous crops (hemp, jute, ramie, and kenaf), flax represents the most economically important species and the majority of studies on metal contaminated soil for the phytoextraction of heavy metals have been conducted using flax. Therefore, a comprehensive review is needed for a better understanding of the phytoremediation potential of flax when grown in metal contaminated soil. This review describes the existing studies related to the phytoremediation potential of flax in different mediums such as soil and water. After phytoremediation, flax has the potential to be used for additional purposes such as linseed oil, fiber, and important livestock feed. This review also describes the phytoremediation potential of flax when grown in metal contaminated soil. Furthermore, techniques and methods to increase plant growth and biomass are also discussed in this work. However, future research is needed for a better understanding of the physiology, biochemistry, anatomy, and molecular biology of flax for increasing its pollutant removal efficiency.
\end{abstract}

Keywords: Linum usitatissimum (flax); heavy metals; phytoremediation; chelating agents; environmental pollution 


\section{Introduction}

Most heavy metals are produced by pollution and their presence causes many ecological, evolutionary, and nutritional problems. Many risks are created due to heavy metal contamination, like soil pollution as well as security of food and its quality [1-6]. Heavy metals cause many harmful effects for living things, including plants. They decrease the growth and development of plants even at low concentrations of heavy metals with respect to other metals. Excess amounts of other metals or elements do not damage the tissues/cells of the plant, and their accumulation can even increase the growth of the plant [7-11]. The metals which are lethal or harmful for plants include: lead, cadmium, cobalt, iron, silver, platinum, nickel, chromium, copper, and zinc. Agricultural soil is befouled by many heavy metals, which is a major issue. Many anthropogenic activities effect soil and the effectiveness of the plant, like urbanization, smelting, sludge, military operations, mining, dumping, and excess amounts of pesticide and insecticide applications [3,5,10,12-14]. These activities inhibit the growth of the plants and cause many toxic symptoms in the plants due to heavy metal contamination, and these metals destroy human health by entering into the food chain [15-17]. However, the metal contaminants are useful in fertilization as well as in pesticides, fungicides, and nematicides for the better production and development of the plant. These applications are a major source for the growth of the plants. Metal deposition in soil is produced due to biomass and an increase in plant growth [3,18].

The chemical composition, plant type and their species, and the $\mathrm{pH}$ of heavy metals all impact the phytotoxicity of the heavy metals in the plants. A large amount of reacting oxygen species and oxidative stress are involved through direct and indirect toxicity of heavy metals and produced in the following ways: (a) reduction of electrons, (b) the irregular management of metabolic pathways, (c) the activities of anti-oxidative enzymes are reduced, and (d) depletion of lower molecular weight compounds [19-22]. Crop yield and productivity can be improved and the health risk decreased acutely by removing the harmful effects of these heavy metals [23-25].

For the removal of toxic heavy metals from the soil, two methods are usually used. The first is the physical-chemical technology method and the second is the conventional method. These methods are not widely used and may be costly because these methods are not eco-friendly. Some factors involved in these methods include: vapor extraction, stabilization, solidification, soil flushing, soil washing, thermal desorption, and incineration, etc. Some drawbacks are also involved in these methods. For example, they require constant monitoring, exact results through keen performance, and a large monetary cost. Through these methods, pollutants can be removed but harmful effects can be created for the environment due to spreading of pollutants, excavation, and handling, which are toxic [26,27]. Along with these drawbacks, one of the most effective, cheap, and environmental-friendly methods used for the removal of toxic substances which accumulate in the different parts of the plants, like in roots, leaves, branches, and stems, is known as phytoremediation [28]. This method is also used for the reduction of the metal content of soil, the assembly of very large amounts of toxic metal contents through repeating harvesting, and the cycling of planting of the plant species [29,30]. The phytoremediation mechanism is species-specific, which is mostly built upon some anatomical and morphological as well as physiological characteristics of the plants [4,26,31-35]. Phytoremediation is a technology which is widely applicable for metal contaminated areas, with some long-term aesthetic merits and it is famous due to its low cost and eco-friendly nature, so it is used on large scale areas with high contents of heavy metals due to some industry or mining activities.

Another method for the removal of toxic substances like heavy metals is "hyper accumulation," which is widely used and uses the genetic potential of the roots of plants originating from contaminated areas [9,36]. Different plants have different methods for the removal and accumulation of different substances like nutrients and organic materials. For example, some plants have the ability to immobilize or absorb metal pollutants, and some plants can metabolize and accumulate organic species and nutrient contaminants. Many phytoremediation processes are possible through better relationships in between plants, microbes, soil, and contaminants. There are five different methods of utilizing the phytoremediation: (1) phytotransformation, (2) rhizosphere bioremediation, (3) phytostabilization, 
(4) phytoextraction, and (5) rhizofiltration. These five different processes of phytoremediation perform different functions and are different management options for better end products $[13,26]$. The mechanisms of different types of phytoremediation in plants with different management options of the end product are presented in Figure 1.

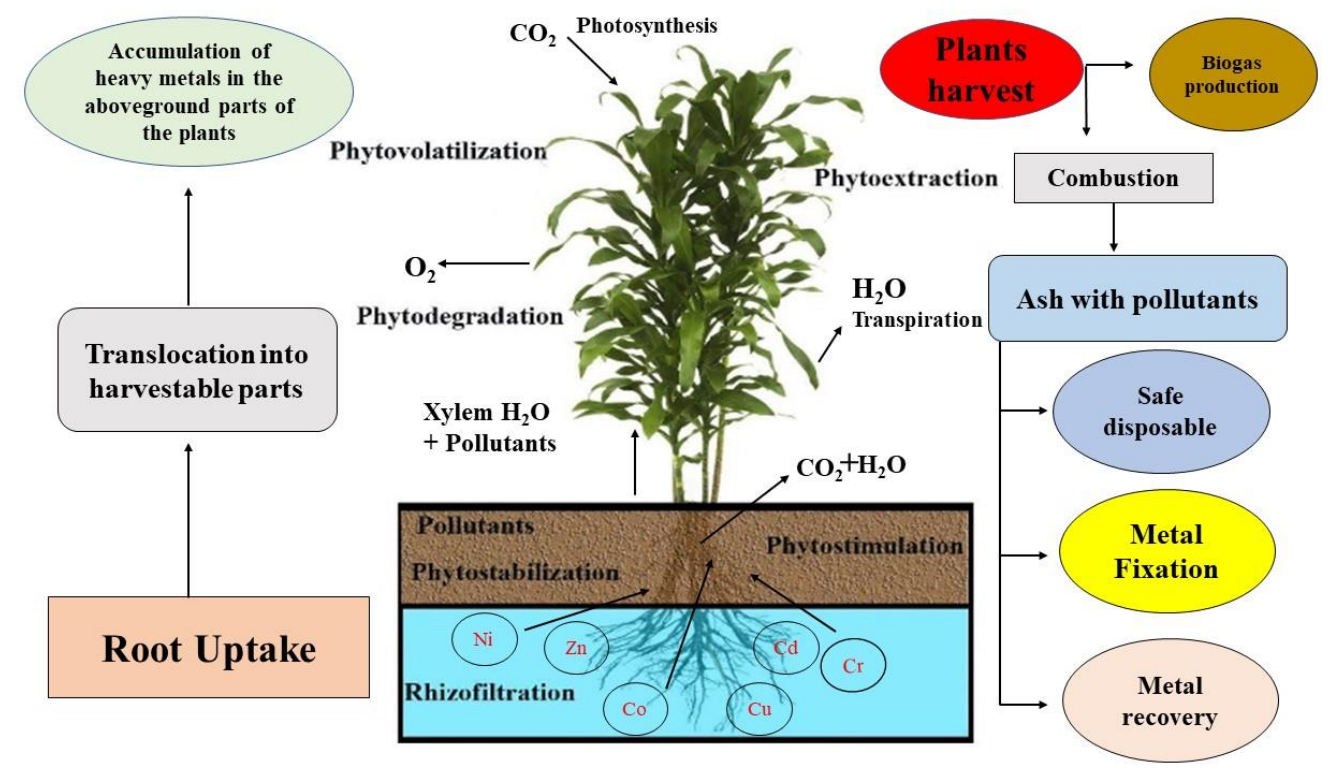

Figure 1. The mechanisms of different types of phytoremediation in plants with different management options of the end product.

Hyper accumulator plants play a significant role in accumulating toxic heavy metals and absorb them in their roots and aboveground parts, which demonstrates that plants have the genetic potential to remove these toxic heavy metals from metal contaminated areas [15,37-39]. Phytoextraction is the most common method of contaminant removal, in which plant species have a huge biomass and accumulate a large amount of heavy metals in their above ground parts. This method depends on the abnormal capability of some plant species in accumulating heavy metals, and heavy metal tolerance is essential for plants used in phytoremediation methods. It is very important to select a plant species with a large biomass and great ability to accumulate heavy metals from the soil [31]. It is well known that heavy metals such as $\mathrm{Cd}, \mathrm{Ni}, \mathrm{Zn}, \mathrm{As}, \mathrm{Se}$, and $\mathrm{Cu}$ are readily bioavailable for plants while $\mathrm{Co}, \mathrm{Mn}$, and $\mathrm{Fe}$ are moderately available, and $\mathrm{Pb}, \mathrm{Cr}$, and $\mathrm{U}$ are not easily available for plants. $\mathrm{Pb}, \mathrm{Cr}$, and $\mathrm{U}$ can be removed by binding to soils and root masses via rhizofiltration [29]. According to the different available literature on phytoremediation, we can say the purposes of phytoremediation are (i) risk containment, (ii) phytoextraction of metals with market value, such as Ni, Tl, and Au, and (iii) durable land management $[29,40]$.

Flax (Linum usitatissimum L.), also known as common flax or linseed, is a fibrous crop and dicotyledonous plant belonging to the family Linaceae with potential economic value [12,41]. Flax is a bluish-flowered plant and has been used for fiber and food purposes in mainly the cooler regions of the world. It is an annual, herbaceous plant found significantly in many countries like China, Russia, and Canada. Flax is one of the oldest fibrous crops, and has been cultivated in China and India for 5000 years and was cultivated in Egypt and Samaria 10,000 years ago [42,43]. The first cultivations of flax in European countries were in Switzerland, Scotland, and Poland. Flax is also grown as an ornamental plant in gardens because of its attractive flowers. Flax has been used as fiber and also for the flaxseed. Flax fiber (which is three times stronger than cotton) is used to make linen in many textile industries due to its natural ability to straighten. Flax fiber is very long also used for the manufacture of decorative fabrics, solid yarn, cordage, and tires [37,44]. Flaxseeds have many nutritional characteristics and contain a high concentration of short-chain omega- 3 fatty acids. Flax is 
mainly cultivated for its fiber but its seeds are edible and can prevent heart disease, cancer, strokes, and diabetes $[45,46]$. Flaxseed contains $20-25 \%$ protein and $40-45 \%$ fatty acids. Flaxseed also produces vegetable oils hence also known as 'linseed oil', which is an edible oil considered one of the oldest commercial oils and which is also used for pharmaceutical purposes. Flaxseed oil is used as a drying oil agent in many counties in the form of processed solvents. Flaxseed is also used commercially as varnishes and paints. The major producers of flax are Canada, Russia, China, Kazakhstan, the United States of America, and India as shown in Figure 2 [47].

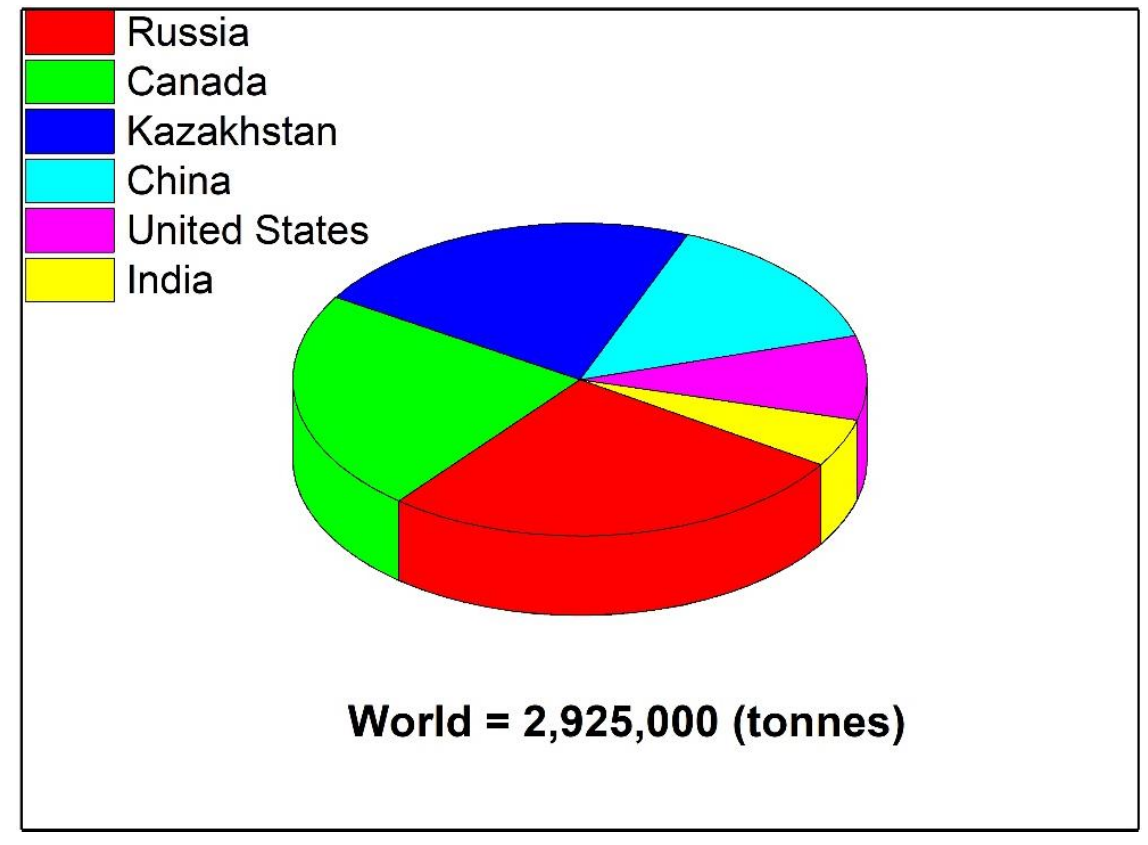

Figure 2. Some major flax producing countries of the world.

For accumulation and phytoextraction of toxic heavy metals such as lead, arsenic, etc., previous investigations have been conducted [48-54]. Flax shows a resistance against heavy metals so is an excellent candidate for phytoremediation when grown on metal contaminated soil. Flax is commercially a very important crop used for linseed oil and fiber and significant information is available regarding using flax as a phytoremediation plant in different heavy metal contaminated soils. There has been a growing interest in using this fibrous species for the phytoremediation of different heavy metals. To the best of our knowledge, there has been a lot of investigation using flax for the phytoremediation of heavy metals but no comprehensive review literature is available on this kind of study. In the present literature we will focus on: (a) studies related to phytoremediation of flax, (b) some major characteristics of flax which made it an excellent candidate for phytoremediation, (c) some additional benefits of flax after cultivation on metal contaminated soil, and (d) applications of chelating plant hormones which can increase phytoremediation potential of flax.

\section{Growth, Morphology, and Habitat}

Flax is the oldest fiber crop and grows throughout the world, especially in the colder regions. Flax is cultivated for its fiber, seed, and as ornamental plants in many gardens. Russia is the biggest exporter of flax but the best quality of flax for fiber extraction is grown in Belgium. With the increase in the market demand for fiber and flaxseed, flax cultivation also needs to increase [55,56]. The flax plant

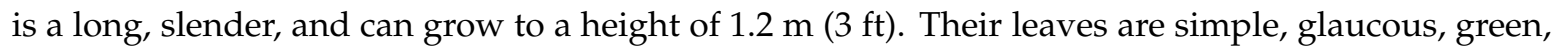
and linear-lanceolate and $3 \mathrm{~mm}$ broad and 20-40 $\mathrm{mm}$ long [41,57]. Most of the varieties of flax are annual, but some are perennial plants. The flowers have five petals of different colors including white, blue, yellow, and red depending on the species, and are hermaphrodite and hypogynous. The fruit is a 
round and dry capsule containing many glossy brown seeds composed of five carpels. The roots are fibrous, shallow, and primary roots divide into many lateral roots with numerous branches. Moreover, the roots are straight and can reach a depth of $1.2 \mathrm{~m}$. With diameters ranging from 1.2-2 mm, the flax stem is round to oval. Seeds contain $35-45 \%$ oil rich in unsaturated fatty acids (FA) as well as $20-25 \%$ protein. The standard FA composition in commercial flax and linseed cultivars is $52-60 \%$ $\alpha$-linolenic (18:3) acids, $2 \%$ stearic (18:0), 6\% palmitic (16:0), and 13-18\% linoleic (18:2) acids, as well as $16-20 \%$ oleic $(18: 1)$ acid. Flax is cultivated for two major reasons: for obtaining fiber and for its seeds. If flax is cultivated for its seeds, it requires a type of soil similar to the one used for cultivation of wheat, i.e., rich with nutrients. It requires a deep, moist, sandy, well-aged soil containing animal manure. If the flax is cultivated for its fiber, it requires deep, fertile, well-drained soil prepared as when growing vegetables.

Flax thrives best in moist regions with a warm climate-free of late frosts in spring, with sufficient moisture during the growing period and where long, continued rainy spells do not alternate with long, continued dryness. Flax can grow well in cool weather, but sowing depends upon the area. Flax requires a relative humidity of $50-60 \%$ with 7 inches of annual rainfall for the best quality yield. Flax can reach its maturity in just 100 days, and it is a good rotational crop [41]. Plants become mature after 100 days or two weeks after the seeds capsules form, and plants turn yellow while the fiber degrades and then plants turn brown. There are two methods for harvesting a flax fiber crop, mechanical and manual methods. The mature seeds are $2 \mathrm{~mm}$ long and very rich in oil [55,56]. Some essential plants which are considered good candidates for phytoremediation and their comparison with the flax plants are presented in Table 1.

Table 1. Some essential plants which are considered good candidates for phytoremediation and comparison with the phytoremediation potential and significant characteristics of flax.

\begin{tabular}{|c|c|c|c|c|c|}
\hline Plant Species & Major Characteristics & Phytoremediation Potential & References & Remarks & References \\
\hline $\begin{array}{c}\text { Chinese } \\
\text { mustard } \\
\text { (Brassica juncea) }\end{array}$ & $\begin{array}{l}\text { It is also known as green mustard } \\
\text { cabbage, Indian mustard, mustard green, } \\
\text { or leaf mustard with edible leaves, stem, } \\
\text { and seeds. The vegetative parts of this } \\
\text { mustard are consumable, cooked or raw. }\end{array}$ & $\begin{array}{l}\text { It was reported that Chinese } \\
\text { mustard has huge biomass } \\
\text { and can accumulate an } \\
\text { impressive amount of } C d \text { in } \\
\text { their above-ground parts. }\end{array}$ & [58] & $\begin{array}{c}\text { Cd is the most frequently } \\
\text { studied element in flax plants } \\
\text { while the presence of high Cd } \\
\text { in soil causes chronic toxicity } \\
\text { in humans. }\end{array}$ & [59] \\
\hline $\begin{array}{l}\text { Chinese ladder } \\
\text { brake fern } \\
\text { (Pteris vittata) }\end{array}$ & $\begin{array}{l}\text { It is native to China and found in many } \\
\text { counties of South America and North } \\
\text { America. It has a very close resemblance } \\
\text { to the swamp fern Blechnum serrulatum }\end{array}$ & $\begin{array}{l}\text { The Chinese brake fern has an } \\
\text { exceptional ability to } \\
\text { accumulate a high amount of } \\
\text { As from the soil. It can consist } \\
\text { of up to } 2 \% \text { arsenite. }\end{array}$ & [60] & $\begin{array}{l}\text { It was noted that among } \\
\text { different heavy metals flax has } \\
\text { potential to remove the most } \\
\text { amount of As from } \\
\text { contaminated soil. }\end{array}$ & [61] \\
\hline $\begin{array}{l}\text { Pennycress } \\
\text { (Thlaspi } \\
\text { Caerulescens) }\end{array}$ & $\begin{array}{l}\text { Pennycress is a biennial herbaceous plant } \\
\text { belonging to the family Brassicaceae. It is } \\
\text { a flowering plant and found in Europe } \\
\text { and Scandinavia. It also grows on } \\
\text { gardens, forest margins, and bare places. }\end{array}$ & $\begin{array}{l}\text { Pennycress can accumulate } \\
\text { and tolerate } \mathrm{Zn}, \mathrm{Cd} \text {, and Ni. It } \\
\quad \text { frequently occurs on } \\
\text { mineralized soils, particularly } \\
\text { those with high } \mathrm{Zn} \text { content. }\end{array}$ & [62] & $\begin{array}{l}\text { When flax grows under } \\
\text { different heavy metals }(\mathrm{Cd}, \mathrm{Zn} \text {, } \\
\text { and } \mathrm{Pb}) \text {, a progressive } \\
\text { decrease in heavy metal } \\
\text { content from the soil was } \\
\text { observed. }\end{array}$ & [53] \\
\hline $\begin{array}{l}\text { Fescue } \\
\text { (Festuca } \\
\text { arundinacea) }\end{array}$ & $\begin{array}{l}\text { Fescue is a genus of flowering plants and } \\
\text { belongs to the family Poaceae. They are } \\
\text { evergreen, and herbaceous plants can } \\
\text { reach a height of } 200 \mathrm{~cm} \text {. It is used as an } \\
\text { ornamental plant and tough grasses. }\end{array}$ & $\begin{array}{l}\text { Fescue has been used for the } \\
\text { phytoremediation of Pb and } \\
\mathrm{Zn} \text { and many other heavy } \\
\text { metals and is thus considered } \\
\text { as a potential candidate for } \\
\text { phytoremediation. }\end{array}$ & [65] & $\begin{array}{l}\text { Flax has huge biomass and can } \\
\text { remove } 253 \mathrm{mg} \mathrm{kg}^{-1} \mathrm{Cu} \text { from } \\
600 \mathrm{mg} \mathrm{kg}^{-1} \mathrm{Cu} \text { in the soil. }\end{array}$ & [12] \\
\hline
\end{tabular}

\section{Plant Selection Considerations}

There is diversity in plants with a vast range in ability to accumulate heavy metal ions. It had been noticed in recent research that metal concentrations of plants grown in the same soil vary from species to species and sometimes between genotypes of plants $[66,67]$. For heavy metal phytoremediation, plant vegetation should be fast-growing and hardy, easy to cultivate and maintain, and able to transport toxic heavy metals in their above-ground parts as well as through the process of evaporation utilizing an excessive amount of water [27]. Due to the unique properties of pheratophytes, such as deep root 
systems and fast growth, as well as a large number of stomata in their leaves (high transpiration rate) and the fact that these plants are often native throughout the country of interest, they have been most often selected for phytoremediation in hotter regions of world. For terrestrial species, hybrid poplar is often selected and coontail is selected for aquatic species. In petroleum-contaminated soils, some species like barley, apple, and orange are used because of their ability to secret phenolic and flavonoids compounds $[35,68]$. Some grasses are also cultivated on tress sites to absorb extra nutrients from the soil. These grasses have tremendously large roots which bind and transform hydrophobic pollutants. These grasses are sown around the trees, which protect them from soil erosion and wind, and remove toxic contaminants from the soil and provide stabilization. Some shrubs also show resistance against heavy metals, such as Atriplex, Maireana, and Glycyrrhiza glabra, while Sesani and alfalfa grasses are also recommended. Many researchers are also working on metal-contaminated sites where these plants are used for phytoremediation [14,69].

Usually, plants are selected for phytoremediation according to the contaminant of concern as well as the needs of the application. Flax can grow up to 1200 to $1500 \mathrm{~mm}$ in length, and its stem is very long, straight, slender, and has some branches on it. The roots system of flax is fibrous, with shallow and lateral root branches, and can grow deep in the soil up to $1.2 \mathrm{~m}[26,27]$. The stem is round and oval with a width up to $2 \mathrm{~mm}$ while seeds are rich with nutrients and have many medicinal applications. All these characteristics of flax make it a potential candidate to grow in metal contaminated soils and it can accumulate metal in the order of root $>$ leaves stem $>$ seed $>$ fiber. Thus, flax can be used for phytoremediation and can provide $100 \%$ utilizable raw material which have no harmful residue as well as fully biodegradable waste [64,70,71].

Plant species should be adapted according to the conditions of the soil and environment because they are the major source for phytoremediation and the growth of the plant. The use of prestigious plants for novel applications, such as flax, is very favorable due to their different biological activities such as requiring less maintenance, tolerance against stress conditions, fewer environmental effects and human risks, as well as well accumulating plant tissues over heavy metals [42,43,72]. However, particular fibrous plant species may work the best for the remediation of specific contaminants and can be safely used in circumstances where the possibility of invasive behavior has eliminated. Furthermore, beyond phytoextraction, flax can also be used as linseed oil or for fibers at the post-harvest stage.

\section{Studies Related to Phytoremediation of the Flax Plant}

There were very few studies of flax in heavy metal contaminated soils in the early 1990s. After that, researchers started to cultivate flax in different countries in Europe, especially in Poland. At that time, there were a lot of industries in Europe that polluted the soil by spreading heavy metals. Besides the main products of flax, fiber and flaxseed, researchers also noticed the value of flaxseed in the field of medicine. After that, researchers started working on different heavy metal soils and cultivating flax on these polluted soils. Moreover, many researchers also worked on artificially contaminated soils to find the levels of heavy metals at which flax showed healthy growth and development. The first component of phytoremediation is a biological component, which signifies an existing plant species that shows tolerance and accumulation of heavy metals. These species produce large amounts of above-ground biomass, and metals are transported from below-ground parts to above-ground harvested plant parts. The second component is a technical base component, which contains complex technologies for harvest, growth, regulation of heavy metals by adequate agro-technological actions, and plant protection. Last is the economic component, which comprises the time of extraction, the cost of phytoextraction, and decreases in the cost of the phytoremediation process by adding new products from the heavy metal polluted biomass. There are some studies on flax that was grown under naturally and artificially contaminated soils. We reviewed a few studies associated with diverse heavy metals which are discussed below. Angelova et al. [73] studied flax, hemp, and cotton grown in an industrially polluted region-the Non-Ferrous-Metal Works near Plovdiv, Bulgaria. In their study, they measured the way heavy metals enter the fibrous crops, and the concentrations of heavy metals in 
plant materials (roots, stems, leaves, seeds, flowers). They also noticed in their study that flax was the crop that most strongly absorbed and accumulated heavy metals from the soil, followed by hemp and cotton. Different heavy metals were accumulated in flax plant organs as follows: roots $>$ stems $>$ leaves $>$ seeds. In their conclusion, they revealed that flax is a suitable crop to cultivate on metal contaminated soils, as it removes considerable quantities of heavy metals from the soil with its root system.

Baraniecki et al. [74] studied the bioremediation potential of flax under $\mathrm{Cu}, \mathrm{Cd}, \mathrm{Pb}$, and $\mathrm{Zn}$ contaminated soils of Bulgaria. They noticed that the high concentration of $\mathrm{Cu}, \mathrm{Cd}, \mathrm{Pb}$, and $\mathrm{Zn}$ were accumulated by flax in the order of root $>$ stem $>$ leaves $>$ seed $>$ fiber. The high concentration of these heavy metals significantly reduced plant growth and biomass. Furthermore, elevated levels of $\mathrm{N}$ ratios in the soil did not confirm the expected increase in heavy metal accumulation; the yield of above-ground biomass was higher in polluted soil. Flax removed a high level of these heavy metals from the soil.

Amna et al. [75] studied (Ni) accumulation of mycorrhizal and non-mycorrhizal flax plants under different concentrations of $\mathrm{Ni}$, i.e., 0 (control), 250, 350, and $500 \mathrm{ppm}$. Accumulation of metals was higher in mycorrhizal than the non-mycorrhizal plants. Although very high doses of Ni reduced the plant growth and biomass, the mycorrhizal plants showed significant good growth and development when compared with the non-mycorrhizal plants. The summary was that the flax plants could help in the phytoremediation of $\mathrm{Ni}$ in artificially contaminated soil, while mycorrhizal plants showed significantly better growth than the non-mycorrhizal plant.

Stritsis et al. [76] studied cadmium (Cd) accumulation in a hydroponic environment of two varieties of flax seedlings (ssp. Usitatissimum and cv. Gold Merchant) under different concentrations of $\mathrm{Cd}$, i.e., 0 (control), $0.1,0.25,0.5$, and $1.0 \mu \mathrm{mol} \mathrm{L}^{-1}$. Accumulation of $\mathrm{Cd}$ was higher at $1.0 \mu \mathrm{mol} \mathrm{L}^{-1}$ and $\mathrm{Cd}$ accumulated in the roots as well as the above-ground parts of the plants. The results also depicted that the increase in $\mathrm{Cd}$ concentration affects the growth and biomass of the flax seedlings. As the $\mathrm{Cd}$ concentration was high in the applied solution, all the growth parameters declined continuously. However, flax seedlings accumulate a high level of $\mathrm{Cd}$ in their body parts and show the possibility of phytoremediation.

Saleem et al. [37] conducted a pot experiment using the flax genotype Longya 10 grown Cu-polluted soil which was obtained from a $\mathrm{Cu}$ mining area of Hubei province, China, and mixed with natural soil at the ratio of 0:1 (control), 1:0, 1:1, 1:2, and 1:4. The results from this study depicted that the phytotoxicity of $\mathrm{Cu}$ reduced the plant growth and biomass while initiating development of reactive oxygen species, which suggested that $\mathrm{Cu}$ toxicity caused oxidative damage in the leaves of flax seedlings. They also determined $\mathrm{Cu}$ contents from the polluted soil before and after the experiment and noticed that flax could remove a large amount of $\mathrm{Cu}$ from the soil and can be used as phytoremediation material for Cu-polluted soils.

Belkadhi et al. [77] studied short term exposure of flax seedlings at different levels of $\mathrm{Cd}$, i.e., 0 (control), 50, and $100 \mu \mathrm{M}$. The seeds were soaked in 0 (control), 250, and $1000 \mu \mathrm{M} \mathrm{Cd}$ in Hoagland nutrient solution. Their results depicted that $100 \mu \mathrm{M}$ caused a significant decrease in the percentages of phosphatidylcholine, phosphatidylglycerol, phosphatidylethanolamine, and changes in other components. However, the application of salicylic acid (SA) played a substantial role in protecting these compounds under Cd-stressed conditions.

Smykalova et al. [49] screened 20 different varieties of flax grown in the Czech Republic. Callus-induction and organogenesis in explants at varying levels of $\mathrm{Cd}$ and $\mathrm{Zn}$ were provided in the cultivation medium. Their results depicted that increasing levels of $\mathrm{Cd}$ and $\mathrm{Zn}$ significantly affected the growth of different varieties of flax. In contrast, different varieties accumulated a large amount of heavy metals and thus can be used as a phytoremediation tool for $\mathrm{Cd}$ and $\mathrm{Zn}$ contaminated soils. Furthermore, they also demonstrated that Llona, Tabor, and Merkur are $\mathrm{Zn}$ and $\mathrm{Cd}$ tolerant varieties while Venice, Lola, and Jitka are Cd-accumulating varieties and Viltstar is a $\mathrm{Cd}$ and $\mathrm{Zn}$ sensitive variety. 
Najmanova et al. [52] investigated the capacity of flax varieties and cultivars to accumulate $\mathrm{Cd}$ under different concentrations: 0 (control), 50, 100, 250, 500, or $1000 \mathrm{M} \mathrm{Cd}$. Their results depicted that most of the $\mathrm{Cd}$ was retained in roots, while a little moved to the shoot of the plants. Moreover, a little transformation of $\mathrm{Cd}$ concentration through vascular bundles to the above-ground parts showed that flax seedlings could also accumulate $\mathrm{Cd}$ in their above-ground parts.

Hosman et al. [53] conducted a pot experiment using flax plants as a phytoremediator for metal contaminated soil which was artificially spiked with $\mathrm{Cd}$ (0 (control), 10, 20, and $40 \mathrm{mg} \mathrm{kg}^{-1}$ soil), $\mathrm{Pb}$ (0 (control), 150, 500, and $700 \mathrm{mg} \mathrm{kg}^{-1}$ soil), and Zn (0 (control), 400, 800, and $1000 \mathrm{mg} \mathrm{kg}^{-1}$ soil). Compared to the control, a significant reduction in germination percentage was observed in flax seedlings. Increasing metal concentration in the metal-polluted soil caused a significant increase in the metal uptake by the plant. Flax was able to accumulate a large amount of heavy metals from the soil while the values of bioaccumulation factor (BAF) and translocation factor (TF) were greater than 1 for $\mathrm{Zn}$, and $\mathrm{Pb}$ showed that flax is a hyper accumulator species for both $\mathrm{Zn}$ and $\mathrm{Pb}$. Contrastingly, $\mathrm{BAF}$ and TF were less than 1 for $\mathrm{Cd}$, indicating that flax is a Cd-excluder plant.

Saleem et al. [12] spiked natural soil with different levels of $\mathrm{Cu}$ (0 (control), 200, 400, and 600 $\mathrm{mg} \mathrm{Cu} \mathrm{kg}{ }^{-1}$ ) and used flax as a tool for phytoremediation under controlled conditions. They proved that flax could tolerate up to $400 \mathrm{mg} \mathrm{kg}^{-1} \mathrm{Cu}$ while further increments of metal caused a significant reduction in plant growth and biomass. They also determined $\mathrm{Cu}$ used the digestion method at different stages of the plant growth, i.e., 35, 70, 105, and 140 days after sowing (DAS). Their results also suggested that in the early stage of the life cycle of the plant, $\mathrm{Cu}$ tended to accumulate in the roots and was transported to the shoots at the last stage of the plant life cycle. Furthermore, all the values of BAF and TF were more than 1 which showed that the flax plant is a hyper accumulator species for $\mathrm{Cu}$ polluted soils. Hence, based on the following results, the author concluded that the flax plant has considerable potential to revoke a large amount of $\mathrm{Cu}$ from the polluted soil.

Belkadhi et al. [54] investigated Cd-treated $(100 \mu \mathrm{M})$ flax seedlings with different exogenous levels of salicylic acid (SA) (0 (control), 250, and $1000 \mu \mathrm{M})$ on $\mathrm{H}_{2} \mathrm{O}_{2}$ initiation, protein composition, and $\mathrm{H}_{2} \mathrm{O}_{2}$-scavenging enzymes. Their results depicted that a high concentration of Cd increased $\mathrm{H}_{2} \mathrm{O}_{2}$ levels and was associated with the augmented activities of guaiacol peroxidase, ascorbate peroxidase, catalase, and superoxide dismutase. The leaves of $\mathrm{Cd}$-free flax seedlings pretreated with $\mathrm{SA}$ increased $\mathrm{H}_{2} \mathrm{O}_{2}$ damage to growth and proteins. Moreover, the Cd-treated seedlings primed with SA exhibited a higher $\mathrm{Cd}$ concentration in their tissues, which suggests that SA can enhance the phytoremediation of flax in $\mathrm{Cd}$ contaminated soil. Uptake and accumulation of different heavy metals by flax plant are presented in Table 2.

Table 2. The capacity of the flax plant to accumulate different heavy metals in the shoots $\left(\mathrm{mg} \mathrm{kg}^{-1}\right)$ and roots $\left(\mathrm{mg} \mathrm{kg}^{-1}\right)$ when grown in metal contaminated soils.

\begin{tabular}{|c|c|c|c|c|c|}
\hline Metal Type & Metal in Soil & $\begin{array}{c}\text { Metal Accumulate } \\
\text { by Shoots }\end{array}$ & $\begin{array}{c}\text { Metals Accumulated } \\
\text { by Roots }\end{array}$ & $\begin{array}{l}\text { Experiment } \\
\text { Type }\end{array}$ & References \\
\hline $\mathrm{Zn}$ & 1008 & 255 & - & Pot & [53] \\
\hline $\mathrm{Cd}$ & 41 & 13 & - & Pot & [53] \\
\hline $\mathrm{Pb}$ & 704 & 310 & - & Pot & [53] \\
\hline $\mathrm{Cu}$ & 617 & 814 & 246 & Pot & [12] \\
\hline $\mathrm{Pb}$ & 1100 & 332 & - & Pot & [78] \\
\hline $\mathrm{Zn}$ & 800 & 116 & - & Pot & [78] \\
\hline $\mathrm{Cd}$ & 6 & 49 & - & Pot & [78] \\
\hline $\mathrm{Zn}$ & 100 & 26 & - & Pot & [79] \\
\hline $\mathrm{Cd}$ & 100 & 190 & - & Pot & [79] \\
\hline $\mathrm{Pb}$ & 200 & 104 & 15 & Pot & [80] \\
\hline $\mathrm{Cu}$ & 96 & 31 & 5 & Pot & [80] \\
\hline $\mathrm{Zn}$ & 536 & 213 & 33 & Pot & [80] \\
\hline $\mathrm{Cd}$ & 12 & 9 & 2 & Pot & [80] \\
\hline
\end{tabular}




\section{Value-Added Products}

Flax is cultivated in all over the world for many purposes and has many commercial, medical, and other important applications. For instance, the flax plant is cultivated for dual purposes, i.e., flaxseed oil or for fibers. The flax plant is also known for its health benefits. It is beneficial for the human heart as it has essential proteins and fibers, which reduce cardiovascular problems, appetite, and aid in weight control $[43,81]$. In addition to cardiovascular problems, its seeds are also used for carpal tunnel syndrome and ulcers. Moreover, its seed oil is also used to control blood pressure, rheumatoid arthritis, cholesterol, and many other common diseases in man [82,83]. In addition, flaxseed oil or linseed oil has been ground and pressed to produce natural oil or cooking oil. Flax oil or linseed oil contains alpha-linolenic acid which can be transformed into omega-3 fatty acid, which has many important benefits $[47,84]$. Similar to flaxseed, flaxseed oil may help lower cholesterol levels. The alpha-linolenic acid in flaxseed oil might play a role in decreasing low-density lipoprotein, or cholesterol [56]. A schematic diagram of flaxseed and flax fiber applications is presented in Figure 3.

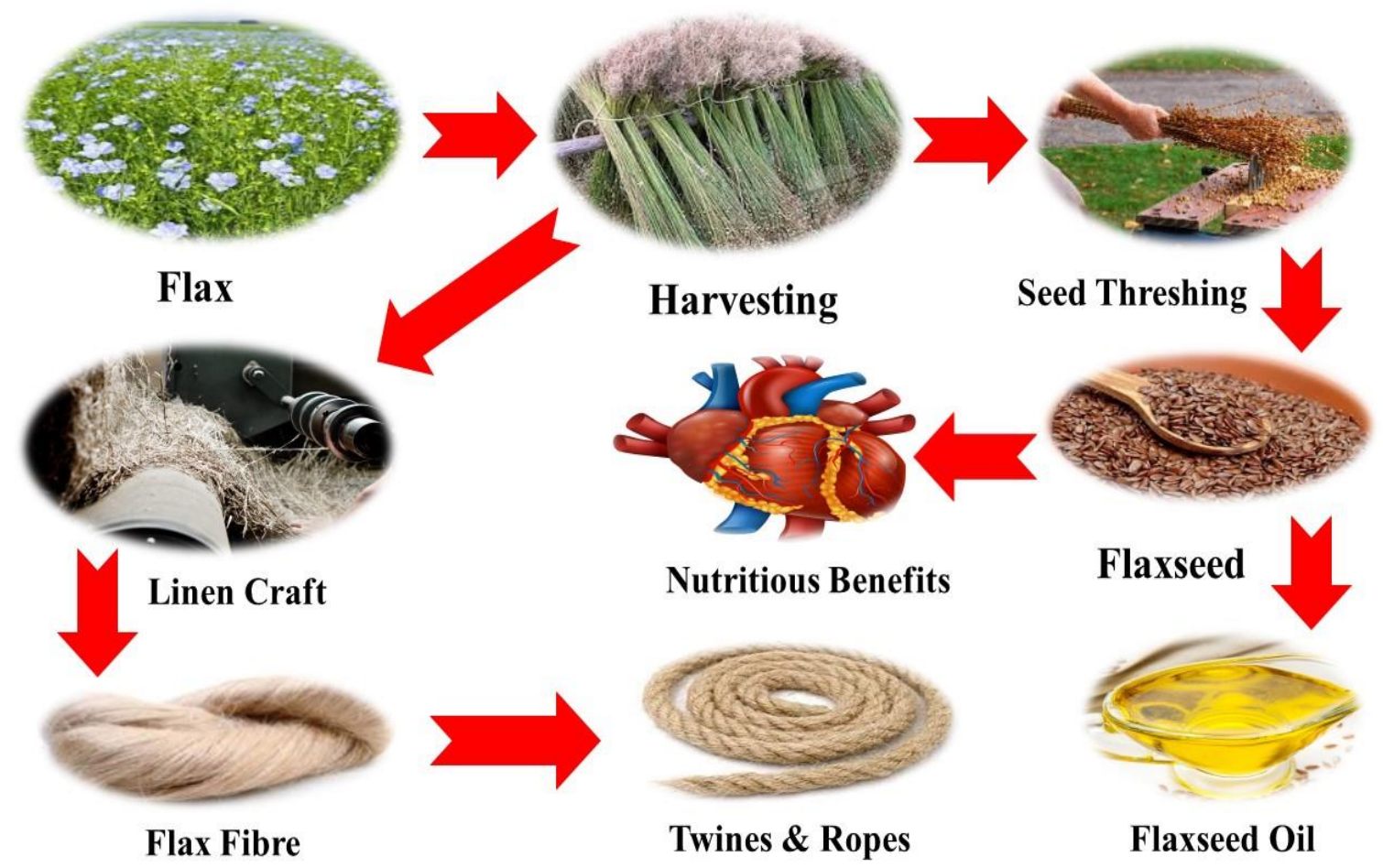

Figure 3. A schematic diagram from the flax field to flax applications.

Recently, flax fiber as reinforcement in composites has become popular due to the increasing demand of the market as a result of globalization. Fibers from flax plants are cost-effective, bio-degradable, and exhibit good chemical characteristics [80,85]. Flax was the first fibrous crop that was spun and woven in to the textiles due to its unique properties. Its fibers contain many important pigments such as cellulose, hemicelluloses, wax, lignin, and pectin, which have been studied/reported by many different studies [46,86]. Flax plants have various compositions of pigments as they depend upon plant variety, soil conditions, and growth treatments. Flax fiber has excellent tensile characteristics analogous to glass fibers [46,57]. A flow chart diagram of flax usage is presented in Figure 4. 


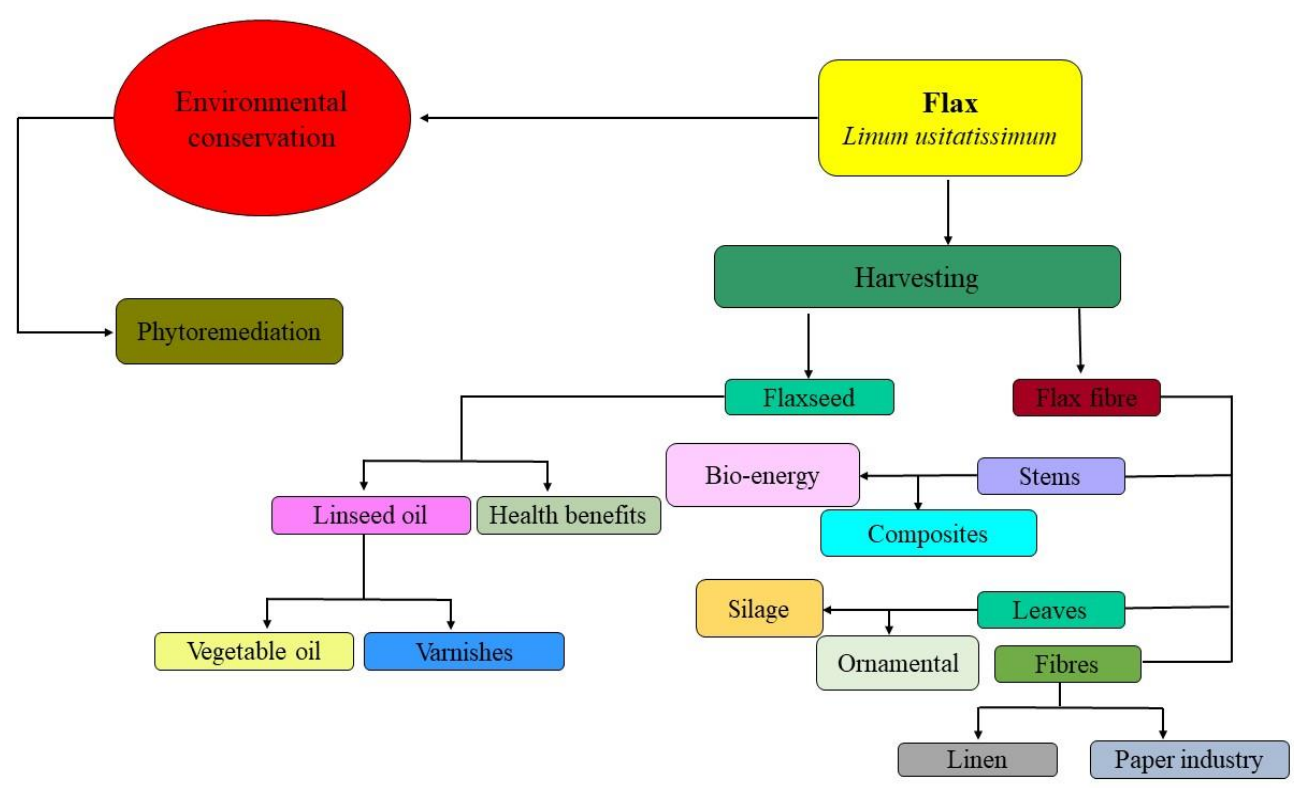

Figure 4. Flow chart diagram of flax usage.

\section{Enhancement of Phytoremediation Potential Using Flax Plants}

The phytoremediation potential of a plant can be increased by using an exogenous application of metallothioneins or chelating agents. These are essential peptides/proteins involved in metal accumulation and tolerance for any plant species. Plant phytochelatins and metallothioneins have cysteine sulfhydryl groups, which bind with metal ions and form complexes $[29,34,87]$. Plant species which have a slow growth rate and chemically mediated phytoremediation in a metal stress environment are most effective. However, plant species with huge biomass and fast growth rates are also cultivated in metal stress environments with the help of chelating agents that help to increase the metal availability for such plant species $[39,88]$. The application of different chelators under metal stress conditions helps to increase metal accumulation and transport within the plant for the development of phytoremediation. In addition to this, the potential of metal absorption in non-hyper accumulator species can be enhanced by the application of such organic chelators. Studies also suggested that different chelating agents are used by the different plant species for extraction and detoxification of heavy metals $[26,29,89,90]$. Metallothioneins are metal-binding proteins with low molecular weights and encoded by specific genes, which help a plant to tolerate metal stress environments [91,92]. By overexpression of natural chelators (metallothioneins and chelating agents), not only the entrance of metal ions into plant cells but also translocation through the xylem are facilitated.

By using flax, the application of chelating agents such as oxalic acid and ethylenediamine-tetra-acetic acid not only increased biomass and phytoremediation potential but also helped in increase the retting effect on flax by the commercial enzyme products Ultrazym and Flaxzyme (Novo Nordisk) as showed by Nörtemann [93]. Although very few studies are available on the effect of different chelating agents or plant growth regulators of metal contaminated soil [94-101], it is an innovative approach. Still, studies are required in the future to explore more improvements to the phytoremediation efficiency of flax.

\section{Conclusions and Future Prospects}

Contaminated water and soil with toxic metals is a critical environmental problem, and there is a need to adopt useful methods for the rehabilitation of our environment. Earlier studies showed that flax is appropriate for the phytoremediation of soil and wastewater. Moreover, it can tolerate harsh environments, and uptake, accumulate, and translocate a broad range of diverse metals. Flax is characterized within fiber crops by a genotype for heavy metal tolerance or accumulation. It was also 
observed that many species are vulnerable to petroleum contaminants but flax has a unique property to tolerate an excessive amount of hydrocarbons and is capable of accumulating a large amount of it in their organs.

In terms of phytoremediation of heavy metals by flax plants, full-scale investigations of the long-term phytoremediation of contaminated sediments are needed to evaluate the influence and the bioavailability of contaminants. These investigations can help researchers to estimate the required time for phytoremediation of a contaminated site. Beside phytoremediation, the flax plant can be used as flaxseed or a fibrous crop. Flaxseed is very important for its flaxseed oil and is thought to treat many diseases in humans, such as cardiovascular diseases and cancer. Flax fiber is naturally very smooth and was very popular in Europe and North America, until cotton overtook flax as the most common plant for making rag-papers. Future research on flax as a phytoremediation tool is very crucial. Long-term research related to the invasiveness and effects of flax on invaded communities may help to develop a feasible control method.

The summarized conclusions of the literature review are as follows:

- Many studies showed that flax is a hyper accumulator (able to accumulate a larger amount of heavy metals in the aboveground parts then the belowground parts of the plants) species for different heavy metals;

- A few studies show that flax can also remove petroleum hydrocarbons from contaminated soil. For this property it is very popular in Middle-Eastern countries;

- Among the different heavy metals, flax can remove $\mathrm{Cd}$ the best, and most studies are related to the phytoremediation of $\mathrm{Cd}$, as discussed in detail by Griga and Bjelková [47];

- Phytoremediation potential and biomass of flax can be improved by using chelating agents or metallothioneins;

- After phytoremediation, the biomass of flax can be used for the production of value-added by-products such as flaxseed oil or fibers.

Funding: This research was funded by the Deanship of Scientific Research at Princess Nourah bint Abdulrahman University through the Fast-track Research Funding Program.

Acknowledgments: This research was funded by the Deanship of Scientific Research at Princess Nourah bint Abdulrahman University through the Fast-track Research Funding Program. The authors would like to extend their sincere appreciation to the Government College University, Faisalabad, Pakistan for support.

Conflicts of Interest: The authors declare no conflict of interest.

\section{References}

1. Eissa, M.A.; Almaroai, Y.A. Phytoremediation Capacity of Some Forage Plants Grown on a Metals-Contaminated Soil. Soil Sediment Contam. Int. J. 2019, 28, 569-581. [CrossRef]

2. Mahar, A.; Wang, P.; Ali, A.; Awasthi, M.K.; Lahori, A.H.; Wang, Q.; Li, R.; Zhang, Z. Challenges and opportunities in the phytoremediation of heavy metals contaminated soils: A review. Ecotoxicol. Environ. Saf. 2016, 126, 111-121. [CrossRef] [PubMed]

3. Nagajyoti, P.C.; Lee, K.D.; Sreekanth, T. Heavy metals, occurrence and toxicity for plants: A review. Environ. Chem. Lett. 2010, 8, 199-216. [CrossRef]

4. Saleem, M.H.; Ali, S.; Rehman, M.; Hasanuzzaman, M.; Rizwan, M.; Irshad, S.; Shafiq, F.; Iqbal, M.; Alharbi, B.M.; Alnusaire, T.S. Jute: A Potential Candidate for Phytoremediation of Metals-A Review. Plants 2020, 9, 258. [CrossRef] [PubMed]

5. Li, L.; Hou, M.; Cao, L.; Xia, Y.; Shen, Z.; Hu, Z. Glutathione S-transferases modulate Cu tolerance in Oryza sativa. Environ. Exp. Bot. 2018, 155, 313-320. [CrossRef]

6. Rehman, M.; Liu, L.; Wang, Q.; Saleem, M.H.; Bashir, S.; Ullah, S.; Peng, D. Copper environmental toxicology, recent advances, and future outlook: A review. Environ. Sci. Pollut. Res. 2019, 26, 18003-18016. [CrossRef] 
7. Jiang, M.; Liu, S.; Li, Y.; Li, X.; Luo, Z.; Song, H.; Chen, Q. EDTA-facilitated toxic tolerance, absorption and translocation and phytoremediation of lead by dwarf bamboos. Ecotoxicol. Environ. Saf. 2019, 170, 502-512. [CrossRef]

8. Chen, L.; Wang, D.; Zeng, C.; Long, C. Improving Cobalt Phytoextraction by Astragalus Sinicus L. Grown in Co-Contaminated Soils Using Biodegradable Chelators. Soil Sediment Contam. Int. J. 2019, 28, 461-472. [CrossRef]

9. Li, L.; Zhang, K.; Gill, R.A.; Islam, F.; Farooq, M.A.; Wang, J.; Zhou, W. Ecotoxicological and Interactive Effects of Copper and Chromium on Physiochemical, Ultrastructural, and Molecular Profiling in Brassica napus L. BioMed. Res. Int. 2018, 2018, 9248123. [CrossRef]

10. Amna; Masood, S.; Syed, J.H.; Munis, M.F.H.; Chaudhary, H.J. Phyto-extraction of Nickel by Linum usitatissimum in Association with Glomus intraradices. Int. J. Phytoremed. 2015, 17, 981-987. [CrossRef]

11. ul Hassan, Z.; Ali, S.; Rizwan, M.; Hussain, A.; Akbar, Z.; Rasool, N.; Abbas, F. Role of zinc in alleviating heavy metal stress. In Essential Plant Nutrients; Springer: Berlin/Heidelberg, Germany, 2017; pp. 351-366.

12. Feller, U.; Anders, I.; Wei, S. Distribution and Redistribution of 109Cd and 65Zn in the Heavy Metal Hyperaccumulator Solanum nigrum L.: Influence of Cadmium and Zinc Concentrations in the Root Medium. Plants 2019, 8, 340. [CrossRef]

13. Fabbricino, M.; Ferraro, A.; Luongo, V.; Pontoni, L.; Race, M. Soil washing optimization, recycling of the solution, and ecotoxicity assessment for the remediation of Pb-contaminated sites using EDDS. Sustainability 2018, 10, 636. [CrossRef]

14. Adrees, M.; Ali, S.; Rizwan, M.; Zia-ur-Rehman, M.; Ibrahim, M.; Abbas, F.; Farid, M.; Qayyum, M.F.; Irshad, M.K. Mechanisms of silicon-mediated alleviation of heavy metal toxicity in plants: A review. Ecotoxicol. Environ. Saf. 2015, 119, 186-197. [CrossRef] [PubMed]

15. Tan, J.; He, S.; Yan, S.; Li, Y.; Li, H.; Zhang, H.; Zhao, L.; Li, L. Exogenous EDDS modifies copper-induced various toxic responses in rice. Protoplasma 2014, 251, 1213-1221. [CrossRef] [PubMed]

16. Xiao, T.; Mi, M.; Wang, C.; Qian, M.; Chen, Y.; Zheng, L.; Zhang, H.; Hu, Z.; Shen, Z.; Xia, Y. A methionine-R-sulfoxide reductase, OsMSRB5, is required for rice defense against copper toxicity. Environ. Exp. Bot. 2018, 153, 45-53. [CrossRef]

17. Adrees, M.; Ali, S.; Rizwan, M.; Ibrahim, M.; Abbas, F.; Farid, M.; Zia-ur-Rehman, M.; Irshad, M.K.; Bharwana, S.A. The effect of excess copper on growth and physiology of important food crops: A review. Environ. Sci. Pollut. Res. 2015, 22, 8148-8162. [CrossRef]

18. Al Naggar, Y.; Khalil, M.S.; Ghorab, M.A. Environmental pollution by heavy metals in the aquatic ecosystems of Egypt. Open Acc. J. Toxicol. 2018, 3, 555603.

19. Zaheer, I.E.; Ali, S.; Rizwan, M.; Farid, M.; Shakoor, M.B.; Gill, R.A.; Najeeb, U.; Iqbal, N.; Ahmad, R. Citric acid assisted phytoremediation of copper by Brassica napus L. Ecotoxicol. Environ. Saf. 2015, 120, 310-317. [CrossRef]

20. Wuana, R.A.; Okieimen, F.E. Heavy metals in contaminated soils: A review of sources, chemistry, risks and best available strategies for remediation. ISRN Ecol. 2011, 2011, 402647. [CrossRef]

21. Kamran, M.; Malik, Z.; Parveen, A.; Huang, L.; Riaz, M.; Bashir, S.; Mustafa, A.; Abbasi, G.H.; Xue, B.; Ali, U. Ameliorative Effects of Biochar on Rapeseed (Brassica napus L.) Growth and Heavy Metal Immobilization in Soil Irrigated with Untreated Wastewater. J. Plant Growth Regul. 2019, 1-16. [CrossRef]

22. Chen, $\mathrm{X} . ; \mathrm{Lu}, \mathrm{X}$. Contamination characteristics and source apportionment of heavy metals in topsoil from an area in Xi'an city, China. Ecotoxicol. Environ. Saf. 2018, 151, 153-160. [CrossRef]

23. Chen, J.; Shafi, M.; Li, S.; Wang, Y.; Wu, J.; Ye, Z.; Peng, D.; Yan, W.; Liu, D. Copper induced oxidative stresses, antioxidant responses and phytoremediation potential of Moso bamboo (Phyllostachys pubescens). Sci. Rep. 2015, 5, 13554. [CrossRef] [PubMed]

24. Jan, R.; Khan, M.A.; Asaf, S.; Lee, I.-J.; Kim, K.M. Metal Resistant Endophytic Bacteria Reduces Cadmium, Nickel Toxicity, and Enhances Expression of Metal Stress Related Genes with Improved Growth of Oryza Sativa, via Regulating Its Antioxidant Machinery and Endogenous Hormones. Plants 2019, 8, 363. [CrossRef] [PubMed]

25. Merrington, G. The good, the bad and the ugly: Copper and arsenic in soils. In Soil Health: The Foundation of Sustainable Agriculture; Wollongbar Agricultural Institute: Wollongbar, Australia, 2018. 
26. Saleem, M.H.; Fahad, S.; Rehman, M.; Saud, S.; Jamal, Y.; Khan, S.; Liu, L. Morpho-physiological traits, biochemical response and phytoextraction potential of short-term copper stress on kenaf (Hibiscus cannabinus L.) seedlings. PeerJ 2020, 8, e8321. [CrossRef] [PubMed]

27. Niazy Abdou, M.; Wahdan, M. Citric Acid-Enhanced Phytoremediation of Lead Using Corchorus capsularis L. and Eucalyptus Camaldulensis; ResearchGate: Berlin, Germany, 2017.

28. Xu, L.; Wang, W.; Guo, J.; Qin, J.; Shi, D.; Li, Y.; Xu, J. Zinc improves salt tolerance by increasing reactive oxygen species scavenging and reducing $\mathrm{Na}^{+}$accumulation in wheat seedlings. Biol. Plant. 2014, 58, 751-757. [CrossRef]

29. Watanabe, M. Phytoremediation on the brink of commercialization. 1997. Environ. Sci. Technol. 1997, 31, 182-186. [CrossRef]

30. Vareda, J.P.; Durães, L. Efficient adsorption of multiple heavy metals with tailored silica aerogel-like materials. Environ. Technol. 2019, 40,529-541. [CrossRef]

31. Muszynska, E.; Hanus-Fajerska, E. Why are heavy metal hyperaccumulating plants so amazing? Biotechnol. J. Biotechnol. Comput. Biol. Bionanotechnol. 2015, 96, 265-271. [CrossRef]

32. Zhang, X.; Zhao, X.; Li, B.; Xia, J.; Miao, Y. SRO1 regulates heavy metal mercury stress response in Arabidopsis thaliana. Chin. Sci. Bull. 2014, 59, 3134-3141. [CrossRef]

33. Ashraf, S.; Ali, Q.; Zahir, Z.A.; Ashraf, S.; Asghar, H.N. Phytoremediation: Environmentally sustainable way for reclamation of heavy metal polluted soils. Ecotoxicol. Environ. Saf. 2019, 174, 714-727. [CrossRef]

34. Ashraf, M.A.; Hussain, I.; Rasheed, R.; Iqbal, M.; Riaz, M.; Arif, M.S. Advances in microbe-assisted reclamation of heavy metal contaminated soils over the last decade: A review. J. Environ. Manag. 2017, 198, 132-143. [CrossRef] [PubMed]

35. Kołaciński, Z.; Rincón, J.; Szymański, T.; Sobiecka, E. Thermal plasma vitrification process as the effective technology for hospital incineration fly ash immobilization. In Vitrification and Geopolimerization of Wastes for Immobilization or Recycling; Universidad Miguel Hernandez: Alicante, Spain, 2017; Volume 51.

36. Saleem, M.; Ali, S.; Rehman, M.; Rana, M.; Rizwan, M.; Kamran, M.; Imran, M.; Riaz, M.; Hussein, M.; Elkelish, A.; et al. Influence of phosphorus on copper phytoextraction via modulating cellular organelles in two jute (Corchorus capsularis L.) varieties grown in a copper mining soil of Hubei Province, China. Chemosphere 2020, 248, 126032. [CrossRef] [PubMed]

37. Zhang, B.; Zheng, J.; Sharp, R. Phytoremediation in engineered wetlands: Mechanisms and applications. Procedia Environ. Sci. 2010, 2, 1315-1325. [CrossRef]

38. Saleem, M.H.; Ali, S.; Irshad, S.; Hussaan, M.; Rizwan, M.; Rana, M.S.; Hashem, A.; Abd_Allah, E.F.; Ahmad, P. Copper Uptake and Accumulation, Ultra-Structural Alteration, and Bast Fibre Yield and Quality of Fibrous Jute (Corchorus capsularis L.) Plants Grown Under Two Different Soils of China. Plants 2020, 9, 404. [CrossRef]

39. Parmar, S.; Singh, V. Phytoremediation approaches for heavy metal pollution: A review. J. Plant Sci. Res. 2015, 2, 135.

40. Yadav, R.; Arora, P.; Kumar, S.; Chaudhury, A. Perspectives for genetic engineering of poplars for enhanced phytoremediation abilities. Ecotoxicology 2010, 19, 1574-1588. [CrossRef]

41. Sangeeta, M.; Maiti, S.K. Phytoremediation of metal enriched mine waste: A review. Am. Eurasian J. Agric. Environ. Sci. 2010, 9, 560-575.

42. Wiszniewska, A.; Hanus-Fajerska, E.; MUSZYŃSKA, E.; Ciarkowska, K. Natural organic amendments for improved phytoremediation of polluted soils: A review of recent progress. Pedosphere 2016, 26, 1-12. [CrossRef]

43. Akhtar, M.S.; Chali, B.; Azam, T. Bioremediation of arsenic and lead by plants and microbes from contaminated soil. Res. Plant Sci. 2013, 1,68-73.

44. Saleem, M.H.; Fahad, S.; Khan, S.U.; Din, M.; Ullah, A.; Sabagh, A.E.; Hossain, A.; Llanes, A.; Liu, L. Copper-induced oxidative stress, initiation of antioxidants and phytoremediation potential of flax (Linum usitatissimum L.) seedlings grown under the mixing of two different soils of China. Environ. Sci. Pollut. Res. 2019. [CrossRef]

45. Saleem, M.H.; Kamran, M.; Zhou, Y.; Parveen, A.; Rehman, M.; Ahmar, S.; Malik, Z.; Mustafa, A.; Anjum, R.M.A.; Wang, B. Appraising growth, oxidative stress and copper phytoextraction potential of flax (Linum usitatissimum L.) grown in soil differentially spiked with copper. J. Environ. Manag. 2020, 257, 109994. 
46. Imran, M.; Sun, X.; Hussain, S.; Ali, U.; Rana, M.S.; Rasul, F.; Saleem, M.H.; Moussa, M.G.; Bhantana, P.; Afzal, J. Molybdenum-Induced Effects on Nitrogen Metabolism Enzymes and Elemental Profile of Winter Wheat (Triticum aestivum L.) Under Different Nitrogen Sources. Int. J. Mol. Sci. 2019, 20, 3009.

47. Griga, M.; Bjelková, M. Flax (Linum usitatissimum L.) and Hemp (Cannabis sativa L.) as fibre crops for phytoextraction of heavy metals: Biological, agro-technological and economical point of view. In Plant-Based Remediation Processes; Springer: Berlin, Germany, 2013; pp. 199-237.

48. Saleem, M.H.; Fahad, S.; Khan, S.U.; Ahmar, S.; Khan, M.H.U.; Rehman, M.; Maqbool, Z.; Liu, L. Morpho-physiological traits, gaseous exchange attributes, and phytoremediation potential of jute (Corchorus capsularis L.) grown in different concentrations of copper-contaminated soil. Ecotoxicol. Environ. Saf. 2020, 189, 109915. [CrossRef] [PubMed]

49. Usman, K.; Al-Ghouti, M.A.; Abu-Dieyeh, M.H. Phytoremediation: Halophytes as Promising Heavy Metal Hyperaccumulators. Heavy Met. 2018. [CrossRef]

50. Rehman, M.; Liu, L.; Bashir, S.; Saleem, M.H.; Chen, C.; Peng, D.; Siddique, K.H. Influence of rice straw biochar on growth, antioxidant capacity and copper uptake in ramie (Boehmeria nivea L.) grown as forage in aged copper-contaminated soil. Plant Physiol. Biochem. 2019, 138, 121-129. [CrossRef]

51. Najeeb, U.; Xu, L.; Ali, S.; Jilani, G.; Gong, H.; Shen, W.; Zhou, W. Citric acid enhances the phytoextraction of manganese and plant growth by alleviating the ultrastructural damages in Juncus effusus L. J. Hazard. Mater. 2009, 170, 1156-1163. [CrossRef]

52. Kanwal, U.; Ali, S.; Shakoor, M.B.; Farid, M.; Hussain, S.; Yasmeen, T.; Adrees, M.; Bharwana, S.A.; Abbas, F. EDTA ameliorates phytoextraction of lead and plant growth by reducing morphological and biochemical injuries in Brassica napus L. under lead stress. Environ. Sci. Pollut. Res. 2014, 21, 9899-9910.

53. Sidhu, G.P.S.; Bali, A.S.; Singh, H.P.; Batish, D.R.; Kohli, R.K. Ethylenediamine disuccinic acid enhanced phytoextraction of nickel from contaminated soils using Coronopus didymus (L.) Sm. Chemosphere 2018, 205, 234-243. [CrossRef]

54. Jiang, L.Y.; Yang, X.; He, Z. Growth response and phytoextraction of copper at different levels in soils by Elsholtzia splendens. Chemosphere 2004, 55, 1179-1187.

55. Saleem, M.H.; Ali, S.; Seleiman, M.F.; Rizwan, M.; Rehman, M.; Akram, N.A.; Liu, L.; Alotaibi, M.; Al-Ashkar, I.; Mubushar, M. Assessing the Correlations between Different Traits in Copper-Sensitive and Copper-Resistant Varieties of Jute (Corchorus capsularis L.). Plants 2019, 8, 545.

56. Ogunkunle, C.O.; Ziyath, A.M.; Adewumi, F.E.; Fatoba, P.O. Bioaccumulation and associated dietary risks of $\mathrm{Pb}, \mathrm{Cd}$, and $\mathrm{Zn}$ in amaranth (Amaranthus cruentus) and jute mallow (Corchorus olitorius) grown on soil irrigated using polluted water from Asa River, Nigeria. Environ. Monit. Assess. 2015, 187, 281. [CrossRef] [PubMed]

57. Uddin Nizam, M.; Mokhlesur Rahman, M.; Kim, J.E. Phytoremediation Potential of Kenaf (Hibiscus cannabinus L.), Mesta (Hibiscus sabdariffa L.), and Jute (Corchorus capsularis L.) in Arsenic-contaminated Soil. Korean J. Environ. Agric. 2016, 35, 111-120. [CrossRef]

58. Abubakari, M.; Moomin, A.; Nyarko, G.; Dawuda, M. Heavy metals concentrations and risk assessment of roselle and jute mallow cultivated with three compost types. Ann. Agric. Sci. 2017, 62, 145-150. [CrossRef]

59. Uddin, M.N.; Wahid-Uz-Zaman, M.; Rahman, M.M.; Islam, M.S.; Islam, M.S. Phytoremediation Potentiality of Lead from Contaminated Soils by Fibrous Crop Varieties. Am. J. Appl. Sci. Res. 2016, 2, 22.

60. Ahmed, D.A.; Slima, D.F. Heavy metal accumulation by Corchorus olitorius L. irrigated with wastewater. Environ. Sci. Pollut. Res. 2018, 25, 14996-15005. [CrossRef]

61. Faruk, O.; Bledzki, A.K.; Fink, H.-P.; Sain, M. Biocomposites reinforced with natural fibers: 2000-2010. Prog. Polym. Sci. 2012, 37, 1552-1596. [CrossRef]

62. Choudhary, S.B.; Sharma, H.K.; Karmakar, P.G.; Kumar, A.; Saha, A.R.; Hazra, P.; Mahapatra, B.S. Nutritional profile of cultivated and wild jute ('Corchorus') species. Aust. J. Crop Sci. 2013, 7, 1973.

63. Thiruchitrambalam, M.; Athijayamani, A.; Sathiyamurthy, S.; Thaheer, A.S.A. A review on the natural fiber-reinforced polymer composites for the development of roselle fiber-reinforced polyester composite. J. Nat. Fibers 2010, 7, 307-323. [CrossRef]

64. Saleem, M.H.; Rehman, M.; Zahid, M.; Imran, M.; Xiang, W.; Liu, L. Morphological changes and antioxidative capacity of jute (Corchorus capsularis, Malvaceae) under different color light-emitting diodes. Braz. J. Bot. 2019. [CrossRef] 
65. Kozlowski, R.; Mieleniak, B.; Helwig, M.; Przepiera, A. Flame resistant lignocellulosic-mineral composite particleboards. Polym. Degrad. Stab. 1999, 64, 523-528. [CrossRef]

66. Bhattacharya, S.; Guha, G.; Gupta, K.; Chattopadhyay, D.; Mukhopadhyay, A.; Ghosh, U.C. Trend of arsenic pollution and subsequent bioaccumulation in Oryza sativa and Corchorus capsularis in Bengal Delta. Int. Lett. Nat. Sci. 2014, 16. [CrossRef]

67. Osundiya, M.; Ayejuyo, O.; Olowu, R.; Bamgboye, O.; Ogunlola, A. Bioaccumulation of heavy metals in frequently consumed leafy vegetable grown along Nigeria-Benin Seme Border, West Africa. Pelagia Res. Libr. 2014, 5, 1-7.

68. Mahapatra, B.; Mitra, S.; Ramasubramanian, T.; Sinha, M. Research on jute (Corchorus olitorius and C. capsularis) and kenaf (Hibiscus cannabinus and H. sabdariffa): Present status and future perspective. Indian J. Agric. Sci. 2014, 79, 951-967.

69. Mohanty, A.; Misra, M. Studies on jute composites-A literature review. Polym. Plast. Technol. Eng. 1995, 34, 729-792. [CrossRef]

70. Haghdan, S.; Smith, G.D. Natural fiber reinforced polyester composites: A literature review. J. Reinf. Plast. Compos. 2015, 34, 1179-1190. [CrossRef]

71. Ndlovu, J.; Afolayan, A. Nutritional analysis of the South African wild vegetable Corchorus olitorius L. Asian J. Plant Sci. 2008, 7, 615-618.

72. Singh, H.; Singh, J.I.P.; Singh, S.; Dhawan, V.; Tiwari, S.K. A Brief Review of Jute Fibre and Its Composites. Mater. Today Proc. 2018, 5, 28427-28437. [CrossRef]

73. Islam, M.; Rahman, M. Hand book on agricultural technologies of Jute, Kenaf and Mesta crops. Bangladesh Jute Res. Inst. Dhaka 2008, 2, 92.

74. Sarwar, N.; Imran, M.; Shaheen, M.R.; Ishaque, W.; Kamran, M.A.; Matloob, A.; Rehim, A.; Hussain, S. Phytoremediation strategies for soils contaminated with heavy metals: Modifications and future perspectives. Chemosphere 2017, 171, 710-721. [CrossRef]

75. Khan, M.N.; Zhang, J.; Luo, T.; Liu, J.; Ni, F.; Rizwan, M.; Fahad, S.; Hu, L. Morpho-physiological and biochemical responses of tolerant and sensitive rapeseed cultivars to drought stress during early seedling growth stage. Acta Physiol. Plant. 2019, 41, 25. [CrossRef]

76. Kamran, M.; Parveen, A.; Ahmar, S.; Malik, Z.; Hussain, S.; Chattha, M.S.; Saleem, M.H.; Adil, M.; Heidari, P.; Chen, J.T. An Overview of Hazardous Impacts of Soil Salinity in Crops, Tolerance Mechanisms, and Amelioration through Selenium Supplementation. Int. J. Mol. Sci. 2019, 21, 148. [CrossRef] [PubMed]

77. Usman, A.R.; Lee, S.S.; Awad, Y.M.; Lim, K.J.; Yang, J.E.; Ok, Y.S. Soil pollution assessment and identification of hyperaccumulating plants in chromated copper arsenate (CCA) contaminated sites, Korea. Chemosphere 2012, 87, 872-878. [CrossRef] [PubMed]

78. Qadir, M.; Oster, J. Vegetative bioremediation of calcareous sodic soils: History, mechanisms, and evaluation. Irrig. Sci. 2002, 21, 91-101.

79. Sharma, H.D.; Reddy, K.R. Geoenvironmental Engineering: Site Remediation, Waste Containment, and Emerging Waste Management Technologies; John Wiley \& Sons: Hoboken, NJ, USA, 2004.

80. Laghlimi, M.; Baghdad, B.; El Hadi, H.; Bouabdli, A. Phytoremediation mechanisms of heavy metal contaminated soils: A review. Open J. Ecol. 2015, 5, 375. [CrossRef]

81. Malik, R.N.; Husain, S.Z.; Nazir, I. Heavy metal contamination and accumulation in soil and wild plant species from industrial area of Islamabad, Pakistan. Pak. J. Bot. 2010, 42, 291-301.

82. Sinha, S.; Mishra, R.; Sinam, G.; Mallick, S.; Gupta, A. Comparative evaluation of metal phytoremediation potential of trees, grasses, and flowering plants from tannery-wastewater-contaminated soil in relation with physicochemical properties. Soil Sediment Contam. Int. J. 2013, 22, 958-983. [CrossRef]

83. Haque, S.; Ferdous, A.S.; Sarker, S.; Islam, M.; Hossain, K.; Khan, H. Identification and expression profiling of microRNAs and their corresponding targets related to phytoremediation of heavy metals in jute (Corchorus olitorius var. O-9897). Biores. Commun. 2016, 2, 152-157.

84. Nwaichi, E.O.; Dhankher, O.P. Heavy metals contaminated environments and the road map with phytoremediation. J. Environ. Prot. 2016, 7, 41. [CrossRef]

85. Oyedele, D.; Asonugho, C.; Awotoye, O. Heavy metals in soil and accumulation by edible vegetables after phosphate fertilizer application. Electron. J. Environ. Agric. Food Chem. 2006, 5, 1446-1453.

86. Anwer, S.; Ashraf, M.Y.; Hussain, M.; Ashraf, M.; Jamil, A. Citric acid mediated phytoextraction of cadmium by maize (Zea mays L.). Pak. J. Bot. 2012, 44, 1831-1836. 
87. Rana, M.; Bhantana, P.; Sun, X.-C.; Imran, M.; Shaaban, M.; Moussa, M.; Saleem, M.H.; Elyamine, A.; Binyamin, R.; Alam, M.; et al. Molybdenum as an Essential Element for Crops: An Overview. Int. J. Scien. Res. Growth 2020, 24, 18535.

88. Rehman, M.; Yang, M.; Fahad, S.; Saleem, M.H.; Liu, L.; Liu, F.; Deng, G. Morpho-physiological traits, antioxidant capacity and nitrogen metabolism in Boehmeria nivea L. under nitrogen fertilizer. Agron. J. 2020. [CrossRef]

89. Hassan, M.; Dagari, M.; Babayo, A. Effect of citric acid on cadmium ion uptake and stress response of hydroponically grown jute mallow (Corchorus olitorius). J. Environ. Anal. Toxicol. 2016, 6, 375.

90. Oguntade, O.A.; Olagbenro, T.S.; Odusanya, O.A.; Olagunju, S.O.; Adewusi, K.M.; Adegoke, A.T. Assessment of composted kitchen waste and poultry manure amendments on growth, yield and heavy metal uptake by Jute mallow Corchorus olitorius Linn. Int. J. Recycl. Org. Waste Agric. 2019, 8, 187-195. [CrossRef]

91. Ogoko, E. Accumulation of heavy metal in soil and their transfer to leafy vegetables with phytoremediation potential. Am. J. Chem. 2015, 5, 125-131.

92. Idirs, S.; Yisa, J.; Ndamitso, M. Nutritional composition of Corchorus olitorius leaves. Anim. Prod. Res. Adv. 2009, 5. [CrossRef]

93. Nörtemann, B. Biodegradation of chelating agents: EDTA, DTPA, PDTA, NTA, and EDDS. Biogeochem. Chelating Agents 2005, 910, 150-170. [CrossRef]

94. Habiba, U.; Ali, S.; Farid, M.; Shakoor, M.B.; Rizwan, M.; Ibrahim, M.; Abbasi, G.H.; Hayat, T.; Ali, B. EDTA enhanced plant growth, antioxidant defense system, and phytoextraction of copper by Brassica napus L. Environ. Sci. Pollut. Res. 2015, 22, 1534-1544. [CrossRef]

95. Afshan, S.; Ali, S.; Bharwana, S.A.; Rizwan, M.; Farid, M.; Abbas, F.; Ibrahim, M.; Mehmood, M.A.; Abbasi, G.H. Citric acid enhances the phytoextraction of chromium, plant growth, and photosynthesis by alleviating the oxidative damages in Brassica napus L. Environ. Sci. Pollut. Res. 2015, 22, 11679-11689. [CrossRef]

96. Mohsin, M.; Kuittinen, S.; Salam, M.M.A.; Peräniemi, S.; Laine, S.; Pulkkinen, P.; Kaipiainen, E.; Vepsäläinen, J.; Pappinen, A. Chelate-assisted phytoextraction: Growth and ecophysiological responses by Salix schwerinii EL Wolf grown in artificially polluted soils. J. Geochem. Explor. 2019, 205, 106335. [CrossRef]

97. Kwak, J.H.; Park, K.; Chang, P.C.; Liu, W.; Kim, J.Y.; Kim, K.W. Influence of phosphate and citric acid on the phytoextraction of as from contaminated soils. Int. J. Environ. Waste Manag. 2013, 11, 1-12. [CrossRef]

98. Han, Y.; Zhang, L.; Gu, J.; Zhao, J.; Fu, J. Citric acid and EDTA on the growth, photosynthetic properties and heavy metal accumulation of Iris halophila Pall. cultivated in $\mathrm{Pb}$ mine tailings. Int. Biodeterior. Biodegrad. 2018, 128, 15-21. [CrossRef]

99. Farid, M.; Ali, S.; Shakoor, M.B.; Bharwana, S.A.; Rizvi, H.; Ehsan, S.; Tauqeer, H.M.; Iftikhar, U.; Hannan, F. EDTA assisted phytoremediation of cadmium, lead and zinc. Int. J. Agron. Plant Prod. 2013, 4, 2833-2846.

100. Ali, S.Y.; Chaudhury, S. EDTA-enhanced phytoextraction by Tagetes sp. and effect on bioconcentration and translocation of heavy metals. Environ. Process. 2016, 3, 735-746. [CrossRef]

101. Ehsan, S.; Ali, S.; Noureen, S.; Mahmood, K.; Farid, M.; Ishaque, W.; Shakoor, M.B.; Rizwan, M. Citric acid assisted phytoremediation of cadmium by Brassica napus L. Ecotoxicol. Environ. Saf. 2014, 106, 164-172. [CrossRef]

(C) 2020 by the authors. Licensee MDPI, Basel, Switzerland. This article is an open access article distributed under the terms and conditions of the Creative Commons Attribution (CC BY) license (http://creativecommons.org/licenses/by/4.0/). 